\section{New Breeding Lines Resistant to Tomato Mosaic Virus and Tomato Spotted Wilt Virus within the 'De la Pera' Tomato Type: UMH 1353 and UMH 1354}

\author{
Santiago García-Martínez, Adrián Grau, Aranzazu Alonso, \\ Fernando Rubio, Pedro Carbonell, and Juan J. Ruiz ${ }^{\mathbf{1}}$ \\ Departamento de Biología Aplicada, Escuela Politécnica Superior de \\ Orihuela, Universidad Miguel Hernández, Carretera de Beniel, Km. 3,2, \\ 03312 Orihuela, Spain
}

Additional index words. ToMV, TSWV, $T m-2^{a}$ gene, $S w-5$ gene

\begin{abstract}
'De la pera' is a tomato landrace that is very popular in a limited area in southeastern Spain. The fruits from this landrace are juicy and have a firm texture, a strong flavor, and a high proportion of seeds and mucilage. The fruit weight ranges between 75 and $125 \mathrm{~g}$, and fruits are elongated-oval to bell-like in shape, with dark green shoulders and no ribs. Like all tomato landraces, De la pera cultivars are highly susceptible to several viruses, such as Tomato mosaic virus (ToMV), Tomato spotted wilt virus (TSWV), and Tomato yellow leaf curl virus (TYLCV) (Picó et al., 2002). A breeding program for introgression of resistance to ToMV, TSWV, and TYLCV into
\end{abstract} several tomato landraces has been carried out over the last 15 years at the Miguel Hernández University (Spain). The breeding line UMH 1203, homozygous for $T m-2^{a}, T y-1$, and $S w$ 5 genes, was the first obtained within the 'De la pera' tomato type (García-Martínez et al., 2012). This breeding line has enabled farmers to obtain acceptable harvests despite intense virus incidence conditions. Nevertheless, important decreases in yield have been reported for this breeding line, ranging between $40 \%$ and $50 \%$ at low virus incidence conditions (García-Martínez et al., 2012). These results are likely due to introgressed genes and/or linkage drag from the wild tomato species from which the resistance genes originally come, as has been previously reported in processing tomatoes (Tanksley et al., 1998) and in tobacco (Lewis et al., 2007). Previous work indicates that the introgression of TYLCV resistance has been responsible for most of the decrease in yield obtained in fresh tomatoes (Rubio et al., 2012). For this reason, breeding lines UMH

Received for publication 9 Dec. 2015. Accepted for publication 24 Feb. 2016.

This work was partially supported by the Spanish MICINN through projects AGL2005-03946, AGL2008-03822, and AGL2011-26957.

We thank Ansley Evans for the language review. ${ }^{1}$ Corresponding author. E-mail: juanj.ruiz@umh.es.
1422 (with only ToMV resistance) and UMH 1415 (with ToMV and TSWV resistance) were developed (García-Martínez et al., 2014). These lines have shown better marketable yields than UMH 1203 and yields similar to those of the traditional De la pera cultivar 21 (P21). Furthermore, the new breeding lines UMH 1353 and UMH 1354 are available for cropping in the spring-summer crop cycle,
${ }^{y}$ Mean of 6-8 plants per plot for two replicates. two replicates. Newman-Keuls's multiple range test $(P<0.05)$. when the level of TYLCV incidence is lower. These new breeding lines UMH 1353 and $\mathrm{UMH}$ 1354, with genetic resistance to ToMV and TSWV, have shown higher marketable yields than the previously developed breeding lines UMH 1422 and UMH 1415 (around 35\% greater in open field trial and ranging between $15 \%$ and $20 \%$ greater in mesh-covered net house trials) (Table 1).

\section{Origin}

The breeding lines UMH 1353 and UMH 1354 were obtained by crossing a De la pera cultivar (accession P21, previously selected for fruit morphological characteristics, uniformity, and high yields) with the commercial cultivar Anastasia $F_{1}$ (Seminis Vegetable Seeds, Saint Louis, MO). Anastasia $\mathrm{F}_{1}$ was used as the donor parent of the $T m-2^{a}$ and $S w-5$ genes (Pérez de Castro et al., 2007), conferring resistance to ToMV and TSWV, respectively. Six generations of backcrossing were performed to the De la pera cultivar using marker-assisted selection for the virusresistance genes (Table 2). Several trials were carried out under different infection conditions (mechanical inoculation for ToMV and natural infection for TSWV) to check for the presence of resistance alleles in the first backcross (BC) generations and to assess the effectiveness of the molecular

Table 1. Yield traits, titratable acidity (TA), and soluble solids content (SSC) of the two new breeding lines. The previously released breeding lines UMH 1415, UMH 1422, and UMH 1203 and De la pera cultivar P21 are included as reference. All the accessions were grown in the spring-summer crop cycle during the last 4 years, under the typical growing conditions of the region. ${ }^{\mathrm{z}}$

\begin{tabular}{lccccc}
\hline \multicolumn{2}{c}{$\begin{array}{c}\text { Marketable yield } \\
\left(\mathrm{kg} / \text { plant }^{\mathrm{y}}\right.\end{array}$} & Avg fruit wt $(\mathrm{g})^{\mathrm{y}}$ & Fruit no. per plant ${ }^{\mathrm{y}}$ & TA $(\mathrm{g} / 100 \mathrm{~g})^{\mathrm{x}}$ & SSC $\left({ }^{\circ} \text { Brix }\right)^{\mathrm{x}}$ \\
\hline Open field, 2011 & & & & & \\
UMH 1353 & $4.89^{\mathrm{w}} \mathrm{c}$ & $90.5 \mathrm{~b}$ & $53.8 \mathrm{c}$ & $0.57 \mathrm{c}$ & 4.59 \\
UMH 1354 & $4.21 \mathrm{c}$ & $80.9 \mathrm{ab}$ & $52.2 \mathrm{c}$ & $0.49 \mathrm{~b}$ & 4.46 \\
UMH 1415 & $3.29 \mathrm{~b}$ & $75.7 \mathrm{a}$ & $43.2 \mathrm{~b}$ & $0.43 \mathrm{~b}$ & 4.31 \\
UMH 1203 & $2.41 \mathrm{a}$ & $76.9 \mathrm{a}$ & $32.1 \mathrm{a}$ & $0.44 \mathrm{~b}$ & 4.52 \\
P21 & $4.54 \mathrm{c}$ & $114.2 \mathrm{c}$ & $40.8 \mathrm{~b}$ & $0.34 \mathrm{a}$ & 4.47 \\
Mesh-covered net house, 2012 & & & & & \\
UMH 1353 & $5.12 \mathrm{c}$ & $86.6 \mathrm{~b}$ & $51.9 \mathrm{c}$ & $0.71 \mathrm{~b}$ & 5.20 \\
UMH 1354 & $4.57 \mathrm{c}$ & $77.6 \mathrm{ab}$ & $50.2 \mathrm{c}$ & $0.69 \mathrm{~b}$ & 5.28 \\
UMH 1422 & $3.94 \mathrm{~b}$ & $80.5 \mathrm{ab}$ & $43.6 \mathrm{~b}$ & $0.57 \mathrm{ab}$ & 5.22 \\
UMH 1415 & $3.79 \mathrm{~b}$ & $94.3 \mathrm{c}$ & $36.6 \mathrm{~b}$ & $0.55 \mathrm{ab}$ & 5.00 \\
UMH 1203 & $2.38 \mathrm{a}$ & $72.5 \mathrm{a}$ & $29.5 \mathrm{a}$ & $0.43 \mathrm{a}$ & 5.17 \\
P21 & $3.56 \mathrm{~b}$ & $82.5 \mathrm{ab}$ & $38.2 \mathrm{~b}$ & $0.48 \mathrm{a}$ & 5.23 \\
Mesh-covered net house, 2013 & & & & \\
UMH 1353 & $5.73 \mathrm{c}$ & $74.2 \mathrm{~b}$ & $77.6 \mathrm{~b}$ & $0.40 \mathrm{~b}$ & $4.57 \mathrm{a}$ \\
UMH 1354 & $4.37 \mathrm{~b}$ & $63.5 \mathrm{ab}$ & $71.7 \mathrm{~b}$ & $0.49 \mathrm{c}$ & $4.58 \mathrm{a}$ \\
UMH 1422 & $3.97 \mathrm{~b}$ & $60.5 \mathrm{ab}$ & $66.3 \mathrm{~b}$ & $0.31 \mathrm{a}$ & $4.74 \mathrm{ab}$ \\
UMH 1415 & $4.09 \mathrm{~b}$ & $60.6 \mathrm{ab}$ & $68.9 \mathrm{~b}$ & $0.36 \mathrm{ab}$ & $4.92 \mathrm{~b}$ \\
UMH 1203 & $2.59 \mathrm{a}$ & $54.9 \mathrm{a}$ & $46.5 \mathrm{a}$ & $0.36 \mathrm{ab}$ & $4.62 \mathrm{a}$ \\
P21 & $3.03 \mathrm{a}$ & $71.3 \mathrm{~b}$ & $42.3 \mathrm{a}$ & $0.35 \mathrm{a}$ & $4.71 \mathrm{ab}$ \\
Mesh-covered net house, 2014 & & & & \\
UMH 1353 & $4.77 \mathrm{bc}$ & $75.1 \mathrm{~b}$ & $64.2 \mathrm{~b}$ & $0.42 \mathrm{c}$ & $5.69 \mathrm{abc}$ \\
UMH 1354 & $4.99 \mathrm{c}$ & $76.6 \mathrm{~b}$ & $65.2 \mathrm{~b}$ & $0.36 \mathrm{~b}$ & $5.48 \mathrm{a}$ \\
UMH 1422 & $4.12 \mathrm{~b}$ & $63.9 \mathrm{a}$ & $64.4 \mathrm{~b}$ & $0.33 \mathrm{~b}$ & $5.59 \mathrm{ab}$ \\
UMH 1415 & $4.32 \mathrm{~b}$ & $66.8 \mathrm{ab}$ & $64.7 \mathrm{~b}$ & $0.35 \mathrm{~b}$ & $5.80 \mathrm{bc}$ \\
UMH 1203 & $2.49 \mathrm{a}$ & $72.1 \mathrm{ab}$ & $35.1 \mathrm{a}$ & $0.29 \mathrm{a}$ & $6.33 \mathrm{~d}$ \\
P21 & $2.55 \mathrm{a}$ & 65.5 & $40.5 \mathrm{a}$ & $0.33 \mathrm{~b}$ & $5.93 \mathrm{c}$ \\
\hline
\end{tabular}

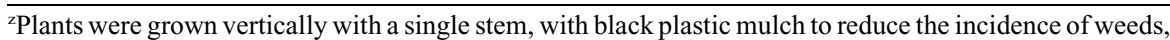
with 2.7 plants $/ \mathrm{m}^{2}$ in open field and 2.5 plants $/ \mathrm{m}^{2}$ in mesh-covered net house.

${ }^{x}$ Mean of 10 fruits in the same stage of ripening (with $>50 \%$ of the surface showing red color) per plot for

${ }^{\text {w}}$ Mean values in a column followed by a different letter are significantly different according to the 
Table 2. Primer sequence, PCR conditions, and restriction enzyme using the molecular markers linked to $T m-2^{a}$ and $S w-5$ genes.

\begin{tabular}{|c|c|c|c|c|}
\hline \multirow[b]{2}{*}{ Gene } & \multirow[b]{2}{*}{ Primer sequence } & \multicolumn{2}{|c|}{ PCR conditions } & \multirow[b]{2}{*}{ Restriction enzyme } \\
\hline & & Cycles (no.) & Annealing temp $\left({ }^{\circ} \mathrm{C}\right)$ & \\
\hline$\overline{T m-2^{a}}$ & AGGTTGTTGCACCGATTGAT & 35 & 55 & $B s u \mathrm{RI}$ \\
\hline$S w-5$ & $\begin{array}{l}\text { AAGCCGAATTATCTGTCAAC } \\
\text { GTTCCTGACCATTACAAAAGTAC }\end{array}$ & 35 & 50 & $\operatorname{Tr} u \mathrm{I}$ \\
\hline
\end{tabular}

Table 3. Genotype for each resistance gene (RR: resistant homozygous, ss: susceptible homozygous) for the two new breeding lines. The UMH 1415, UMH 1422, and UMH 1203 breeding lines and De la pera cultivar P21 are included as reference.

\begin{tabular}{lcll}
\hline & \multicolumn{3}{c}{ Genotype } \\
\cline { 2 - 4 } Breeding line/cultivar & $T m-2^{a}$ & $T y-1$ & $S w-5$ \\
\hline UMH 1353 & RR & ss & RR \\
UMH 1354 & RR & ss & RR \\
UMH 1422 & RR & ss & ss \\
UMH 1415 & RR & ss & RR \\
UMH 1203 & RR & RR & RR \\
P21 & ss & ss & ss \\
\hline
\end{tabular}
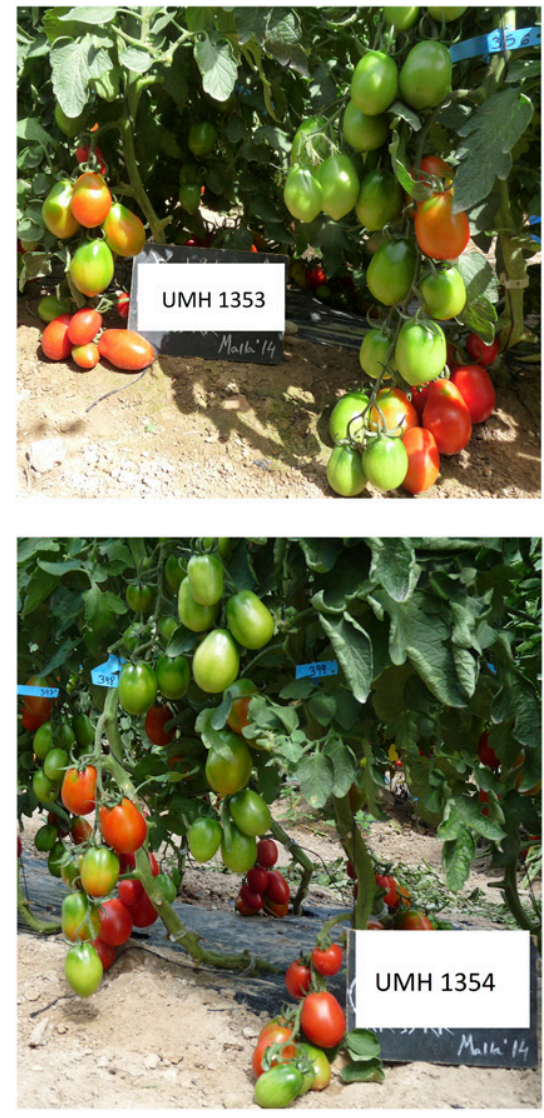

Fig. 1. Plants with fruits in different ripening stages of the breeding lines UMH 1353 and UMH 1354.

markers. In addition, high selection pressure for desirable 'De la pera' characteristics (bell shape, green shoulder, low sensitivity to blossom-end rot) and good agronomic behavior (proper fruit set, sufficient uniformity among fruits and yields) was applied during the backcrossing process. Progenies for each $\mathrm{BC}$ generation were screened with molecular markers for $T m-2^{a}$ and $S w-5$ genes. All plants containing the set of the two resistance genes (usually between five and 10 plants) were transplanted and then crossed with the recurrent parent. Only the best plants (between two and four) were selected for further backcrossing. After the selfing of two $\mathrm{BC}_{6}$ double heterozygous plants, followed by two generations of selfing and selection, the purebreeding UMH 1353 and UMH 1354 lines, homozygous for $T m-2^{a}$ and $S w-5$ (Table 3), were selected using molecular markers. These lines were then multiplied by selfpollination in a greenhouse under controlled conditions.

UMH 1353 and UMH 1354 have indeterminate growth with intermediate foliage density and medium-sized fruits (70-90 g) with bell shape and green shoulders (Fig. 1). Both lines are homozygous for the $T m-2^{a}$ and $S w-5$ resistance genes (Table 3). Between 2011 and 2014, we cultivated UMH 1353 and UMH 1354 breeding lines together with three previously developed breeding lines and the cultivar P21 in different conditions (open field and in mesh-covered net houses) in the spring-summer crop cycle, the most widely used cycle in the traditional area of cultivation for the 'De la pera' tomato. In terms of desirable agronomic traits, UMH 1353 and UMH 1354 surpassed UMH 1203 breeding line that contained resistance to ToMV, TYLCV, and TSWV. The increase in marketable yield was especially significant for the UMH 1353 and UMH 1354 lines, which obtained nearly double the marketable yields of the UMH 1203 line (Table 1). The marketable yields of the UMH 1353 and UMH 1354 breeding lines surpassed the yields of the previously developed breeding lines in three of the four studied cycles. The marketable yields of these new lines ranged between 4.21 $\mathrm{kg} /$ plant and $5.73 \mathrm{~kg} /$ plant, which are high for a tomato landrace. In terms of the number of fruits produced, the increases among the new breeding lines with respect to the previously developed lines were similar to increases in marketable yield (around 50\%). With respect to the average fruit weight, however, differences between the lines were less pronounced, with the new lines showing increases of around $15 \%$ to $20 \%$ with respect to the other lines studied. Furthermore, UMH 1353 and UMH 1354 obtained titratable acidity values similar to or higher than the

\section{Description and Performance}

other breeding lines. In terms of soluble solids content, significant differences were only found in two of the four studied cycles, with the UMH1353 and UMH1354 breeding lines showing similar or lower values with respect to the previously released breeding lines and the traditional cultivar. The small differences between the UMH1353 and UMH1354 breeding lines can be seen in Table 1.

\section{Use}

UMH 1353 and UMH 1354 have genetic resistance to ToMV and TSWV, viruses that often infect tomato landrace crops in southeastern Spain, especially in open field conditions (Cebolla-Cornejo et al., 2007). This study found that $67 \%$ and $18 \%$ of the farms or smallholdings analyzed near the city of Valencia were infected with ToMV and TSWV, respectively. The two new breeding lines UMH 1353 and UMH 1354 are available for cropping in the spring-summer production cycle, which is the most important cycle in the traditional area of cultivation for the 'De la pera' tomato. This is when the level of TYLCV incidence is less intense due to the low population levels of the whitefly vector Bemisia tabaci (Genn.). Cultivation of these breeding lines is also feasible in the summerautumn cycle (when the level of TYLCV incidence is higher), either in greenhouses or mesh-covered net houses with an enclosure in good condition, making it possible to effectively control the vector. As described above, these two new breeding lines have shown higher marketable yields than the previously developed breeding lines. As with previous releases produced by this breeding program, UMH 1353 and UMH 1354 are under study to be marketed by private companies. These breeding lines may be used to develop $F_{1}$ hybrids by crossing them with other 'De la pera' landraces to increase yield by using genetic resistance to ToMV and TSWV in a heterozygous state. Furthermore, these new lines can also be used in breeding programs to facilitate the introgression of these resistance genes into other landraces.

\section{Availability}

Small trial seed samples of all the breeding lines are available for research purposes (please contact authors).

\section{Literature Cited}

Cebolla-Cornejo, J., S. Soler, and F. Nuez. 2007 Genetic erosion of traditional varieties of vegetable crops in Europe: Tomato cultivation in Valencia (Spain) as a case study. Intl. J. Plant Prod. 1(2):113-128.

García-Martínez, S., A. Grau, A. Alonso, F. Rubio, M. Valero, and J.J. Ruiz. 2012. UMH 1203, a multiple virus-resistant fresh-market tomato breeding line for open-field conditions. HortScience 47:124-125.

García-Martínez, S., A. Grau, A. Alonso, F. Rubio, M. Valero, and J.J. Ruiz. 2014. UMH 1422 and UMH 1415: Two fresh-market tomato breeding 
lines resistant to Tomato mosaic virus and Tomato spotted wilt virus. HortScience 49:1465-1466.

Lewis, R.S., L.R. Linger, M.F. Wolff, and E.A. Wernsman. 2007. The negative influence of $N$ mediated TMV resistance on yield in tobacco: Linkage drag versus pleiotropy. Theor. Appl. Genet. 115:169-178.

Pérez de Castro, A., J.M. Blanca, M.J. Díez, and F. Nuez. 2007. Identification of a CAPS marker tightly linked to the Tomato yellow leaf curl disease resistance gene $T y-1$ in tomato. Eur. J. Plant Pathol. 117:347-356.

Picó, B., J. Herraiz, J.J. Ruiz, and F. Nuez. 2002. Widening the genetic basis of virus resistance in tomato. Sci. Hort. 94(1-2):73-89.

Rubio, F., S. García-Martínez, A. Alonso, A. Grau, M. Valero, and J.J. Ruiz. 2012. Introgressing resistance genes into traditional tomato varieties:
Effects on yield and quality. Acta Hort. 935:29-33.

Tanksley, S.D., D. Bernachi, T. Beck-Bunn, D. Emmatty, Y. Eshed, S. Inai, J. Lopez, V. Petiard, H. Sayama, J. Uhlig, and D. Zamir. 1998. Yield and quality evaluations on a pair of processing tomato lines nearly isogenic for the $\mathrm{Tm} 2^{a}$ gene for resistance to the Tobacco mosaic virus. Euphytica 99:77-83. 